\title{
Organizations and Trade
}

\section{Citation}

Antras, Pol, and Esteban Rossi-Hansberg. 2009. Organizations and trade. Annual Review of Economics 1: 43-64.

\section{Published Version}

http://dx.doi.org/10.1146/annurev.economics.050708.143257

\section{Permanent link}

http://nrs.harvard.edu/urn-3:HUL.InstRepos:3199064

\section{Terms of Use}

This article was downloaded from Harvard University's DASH repository, and is made available under the terms and conditions applicable to Open Access Policy Articles, as set forth at http:// nrs.harvard.edu/urn-3:HUL.InstRepos:dash.current.terms-of-use\#OAP

\section{Share Your Story}

The Harvard community has made this article openly available.

Please share how this access benefits you. Submit a story.

\section{Accessibility}




\title{
Organizations and Trade*
}

\author{
Pol Antràs \\ Harvard University
}

\author{
Esteban Rossi-Hansberg \\ Princeton University
}

March 9, 2009

\begin{abstract}
We survey an emerging literature at the intersection of organizational economics and international trade. We argue that a proper modelling of the organizational aspects of production provides valuable insights on the aggregate workings of the world economy. In reviewing the literature, we describe certain predictions of standard models that are affected or even overturned when organizational decisions are brought into the analysis. We also suggest potentially fruitful areas for future research.
\end{abstract}

Keywords: organizations, technology, fragmentation, wage inequality, matching, internalization, contractual frictions, comparative advantage, outsourcing, offshoring.

JEL Classification: D23, E25, F10, F23, L23.

\footnotetext{
*This survey was prepared for the inaugural issue of the Annual Reviews series in Economics. We thank Gene Grossman and Elhanan Helpman for useful comments and Eduardo Morales for very helpful research assistance.
} 


\section{Introduction}

As in standard general equilibrium theory, the three central primitives of traditional and new trade theory are consumer preferences, factor endowments, and the production technologies that allow firms to transform factors of production into consumer goods. As parsimonious as these frameworks are, they have generated some particularly sharp theorems in economics. However, a limitation of these theories is that the specification of technology treats the mapping between factors of production and final goods as a black box. In practice, this mapping is determined by the decisions of agents in organizations.

The growing field of 'Organizational Economics' is devoted to the study of how these organizational decisions shape the mapping between factors of production and consumer goods. An understanding of these microeconomic decisions may be intellectually interesting in its own right: for instance, there is a vast literature trying to understand why certain transactions are carried out within firms and others across firms. In this article, we attempt to convey the notion that studying these organizational decisions provides valuable insights for the aggregate workings of the world economy, and thus the importance of organizational economics transcends the narrow nature of some of the questions it seeks to answer. Only by microfounding the origin and properties of production functions can one fully understand how changes in the economic environment, such as falling trade or communication costs or improvements in contract enforcement, will affect economic outcomes. The classical, reduced-form approach to production technologies will naturally miss the endogenous response of organizations to these changes in the economic environment. We will illustrate the importance of this omission by describing a few predictions of standard models that are dramatically affected or even overturned when organizational decisions are brought into the analysis. As an example, the slicing of the value chain across countries can radically alter the predicted effects of trade integration on relative factor rewards in both developed and developing economies. Also, we shall see how the internalization decision of firms can significantly affect the overall pattern of multinational firm activity around the world.

Although our survey will avoid dwelling into many technical details, it is worth providing a brief formalization of the common theme in the literature we will review. Consider a standard definition of a production function in a country $c$ given by $F_{c}(L)$, where $L$ denotes a vector of traditional inputs (different types of labor and capital, land, etc.). ${ }^{1}$ The main characteristic of these inputs is that their supply is determined outside the production process. For example, aggregate labor supply decisions are made by agents in response to the wages prevailing

\footnotetext{
${ }^{1}$ For simplicity, we abstract here from intermediate inputs. Of course, the use and form of production of certain intermediate goods or services is part of the organizational problem. However, these intermediate goods and services are themselves produced by traditional inputs.
} 
in the economy, not as part of the production process of a firm. $F_{c}(L)$ then denotes the output that can be produced using a set of inputs $L$ in a certain location $c$. The assumption that the specification and parameters of $F_{c}(\cdot)$ are given by technology and are independent of the economic environment assumes away the organizational problem. Now suppose that firms can decide which inputs to use and how to combine them. For example, they can decide to buy some intermediate inputs and produce only part of the production process themselves: an outsourcing decision. The optimal decision on how to produce will determine the characteristics of the function $F_{c}(\cdot)$ and will make those characteristics a function of, potentially, all prices and properties of the economy. Summarize these prices and properties by $\mathcal{E}$. Then the problem of organization becomes one in which the traditional notion of technology is modified to a reduced-form specification given by $O_{c}(L, \mathcal{E})$. Understanding how this production function depends on the characteristics of the economy, namely how the function $O_{c}(\cdot)$ relates to the function $F_{c}(\cdot)$, is the goal of organizational theories. ${ }^{2}$

The key distinction we make in this survey between the 'general' production problem and the organizational problem is that the organizational problem includes only the decisions that shape how a product is produced. The 'general' production problem encompasses both the decisions of what to produce and how to produce it. We therefore think of an organization as all the agents (a firm, a group of firms, or one or several individuals) that participate in a particular production process, given the product itself and its characteristics. As such, the organizational problem includes the decisions of where to locate the different parts of the production process, what type of agents and capital to employ, and whether to produce things in one single firm or outsource part of the production process. These dimensions will guide the ordering of the literature that we propose below. ${ }^{3}$

Trade and organizations are obviously related in as far as the ability to produce part of the production process in different locations determines the characteristics of the organizational problem and the function $O_{c}(\cdot)$. The ability to trade has traditionally been understood, from a country's perspective, as an expansion in the production possibility frontier, since trade can be viewed as an alternative technology to produce the imported goods. In the same way, the ability to organize the production process using foreign factors, technology, institutions, etc. determines the organization of the production process, and therefore the implied 'productivity' of this process. Of course, this link between the organization of production and the

\footnotetext{
${ }^{2}$ Note that the specification of the function $O_{c}(L, \mathcal{E})$ is in general endogenous in organizational theories. However, it is still the case that theories impose many restrictions on the way this function can depend on the characteristics of the economy.

${ }^{3}$ The decision of the number and type of products to produce is, according to our definition, not an organizational decision. In general, this decision has been studied in frameworks that emphasize firm heterogeneity and so we will abstain from discussing it. The interested reader should go to Bernard, Redding and Schott (2006) and Nocke and Yeaple (2008).
} 
ability to incorporate foreign factors and foreign characteristics in the production process via 'trade' has important consequences for welfare. Many of the papers we will review discuss the particular welfare and factor-price implications of this link.

Combining trade theories with organizational theories yields many new predictions in both fields. By incorporating organizational theories into general equilibrium trade models, the literature has obtained a variety of aggregate predictions from these particular ways of understanding the production process. For example, the ability to organize the production process across countries can change the pattern of comparative advantage, and therefore the pattern of trade. Not only are trade models richer and more flexible by incorporating organizational decisions, but organizational theories also gain in richness of predictions and testable implications. For instance, by moving away from the traditional partial-equilibrium, firm-level approaches in organizational economics, some of the papers we will discuss unveil interesting complementarities in the organizational decisions of firms.

Also important in explaining the success and impact of this recent literature is the fact that data on international transactions is particularly accessible: more data on FDI, multinational firms, related party trade, etc. is becoming available every day. This makes the international dimension of the organization decisions of firms a good candidate to empirically explore the predictions of organizational theories, and gain insights into their aggregate importance in the economy.

The remainder of the paper is divided into four sections and a final section with concluding remarks. In dividing the literature into these four sections we have tried to follow a logic that, hopefully, will help the reader. In particular, we have moved progressively from theories that remove certain traditional frictions from classical theories (such as the ability to fragment production or trade tasks), to theories that introduce non-traditional frictions (such as contractual frictions) in order to be able to determine how organizations break down into particular entities, like firms. As a result, the first two sections discuss only the international organization of production and are rich in aggregate predictions, but have nothing to say about the break down of this international organization of production into firms. In contrast, the last two sections introduce contractual frictions in order to have a rich set of predictions on the way the organization of production is broken down into national and multinational firms. Inevitably, these models sacrifice on the richness of the type of organizations considered and on their general equilibrium implications. Of course, these two literatures are complementary and have been developed, to a large extent, in parallel.

In Section 2, we will review a body of work that models the international fragmentation of production across borders in otherwise neoclassical models. Despite the fact that these theories in general share the frictionless environment with traditional theories, we will argue 
that the organizational choices inherent in the international slicing of the value chain can have dramatic consequences for the workings of general-equilibrium models.

In Section 3, we will discuss a literature that further departs from traditional models by relaxing the assumptions that the set of tasks involved in production is fixed, and that factors of production of the same type (say unskilled workers or skilled workers) are perfect substitutes (in efficiency units) from each other. This leads to a nontrivial matching problem between factors of production, which can be interpreted as the organizational design of the production process.

In Section 4, we will focus on a particular organization decision of firms that has received a lot of attention in recent research, namely, the internalization decision of firms. ${ }^{4}$ As we shall discuss, trade statistics have unveiled certain systematic patterns regarding the way that production is being fragmented across borders within and across firms. Because a rationalization of these stylized facts requires a formal model of why some tasks are done within firms, it cannot be provided by complete-contracting frameworks of the type used in traditional theories of international trade. Hence a recent literature has developed general-equilibrium models of multinational production that draw firm boundaries through incomplete contracting.

Finally, in Section 5, we will briefly comment on a few other contributions that have studied the effect of contractual frictions for organizational decisions other than the internalization decision. Section 6 concludes by offering some suggestions for future research in this field.

\section{Fragmentation in Otherwise Neoclassical Models}

Production of a good involves the performance of a set of activities. These different parts of the production process have been labeled tasks, intermediate goods or vertical production stages. In all cases, the main idea in the papers reviewed in this section is that the production process used by firms can be decomposed into these smaller units. None of these studies has anything meaningful to say about the boundaries of the firm; they focus only on the organization of the international production process.

Explicitly recognizing the multi-staged nature of production in models of international trade has been important since the economic environment (e.g. trade costs, information and communication technology, factor prices, etc.) can shape where and how these different tasks or stages of production are performed. In this sense, the possibility, for example, of performing these stages in different countries affects the organization of production. That

\footnotetext{
${ }^{4}$ See Helpman (2006) and Spencer (2005) for recent, alternative reviews of this literature.
} 
is, it affects the reduced form production function (the way in which factors of production are transformed into goods) used by firms in different countries. The possibility to 'trade' these tasks or perform the stages in a different location can have important effects on the measured productivity of firms (as pointed out initially by Jones and Kierkowski, 2001), on the identity of the industries in which countries have comparative advantage (Dixit and Grossman, 1982, Baldwin and Robert-Nicoud, 2007, and Grossman and Rossi-Hansberg, 2008a), and on the implications of trade liberalization or reductions of trade costs on factor prices (Grossman and Rossi-Hansberg, 2008a, and Rodríguez-Clare, 2007). By affecting the location in which each part of the production process is done, trade determines organization, and by determining the way in which the production of these stages determines the 'reduced form' production function, organization determines trade flows. Dixit and Grossman (1982) is the first paper to study this organizational decision in a trade model with a continuum of tasks that differ in their capital-labor ratios.

The unbundling of the production process has been a constant object of study in international trade also because of the ubiquitousness of intermediate good trade and offshoring. Many empirical papers have documented pieces of evidence that point to the unbundling of the production process (see Baldwin and Robert-Nicoud, 2007, for a good discussion of the literature, and Hummels, Ishii and Yi, 2001, and Hanson, Mataloni and Slaughter, 2005 for nice attempts to measure this phenomenon). ${ }^{5}$ More of these 'stages' of production are being done in distinct countries, and so the share of value added of any given country in a particular product has been going down in the last 30 years. Economists have pointed to the role of improvements in communication and transportation technology in explaining these phenomena. As these technologies improve, it becomes more economical to fragment the production process to take advantage of cross-country differences in the cost of performing the necessary tasks, or producing the required intermediate goods. As Grossman and Rossi-Hansberg (2008a) argue, reductions in communication and trade costs imply that by 'trading tasks' or 'unbundling' the production process, firms or organizations can enjoy the productivity benefits of worker specialization without sacrificing the gains from locating production in the most economical location.

The effect of 'unbundling' the production process, as labeled by Baldwin (2006), has been compared to the effect of improvements in technology. Jones and Kierkowski $(1990,2001)$ study a standard factor abundance Hecksher-Ohlin framework with two industries and two factors in which initially production has to be done in only one stage. At some point in

\footnotetext{
${ }^{5}$ There are many problems in measuring the fragmentation of production. Three of the most salient ones are that trade statistics are collected in terms of total value instead of value added, that they tend to insert both final goods and intermediate inputs in the same (finely disaggregated) industry categories, and that some of the traded tasks may not be accurately measured (e.g., managerial tasks).
} 
time, it becomes feasible to fragment the production process in two intermediate goods with different factor intensities within an industry. These stages can be done in distinct countries. Firms will take advantage of this possibility if the two stages have factor intensities that are different enough. The possibility to trade these intermediate stages in an industry is similar to an improvement in total factor productivity in that same industry. The analogy is helpful because much is known about the effect of Hicks neutral technological change in HecksherOhlin models (the early contributions are Findlay and Grubert, 1959, and Jones, 1965). All the standard results apply, so fragmentation leads to overall gains from trade but, in most cases, generates distributional conflict. This is similar to the effect of reductions in trade barriers in the standard Hecksher-Ohlin model. The ability to fragment production can lead, when trading with a poor country that is abundant in unskilled labor, to decreases in the low-skilled workers' wage and to increases in the high-skilled workers' wage. Arndt (1997), Egger and Falkinger (2003), and Kohler (2004a,b) extend this analysis in several directions. In particular, they add the possibility to fragment production in both industries. ${ }^{6}$

Yi (2003) introduces a technology with three sequential stages of production. The emphasis here, relative to Jones and Kierkowski (1990) and similar papers, is the assumption that the stages of production have to been done sequentially (see Hummels, Rapoport and Yi, 1998, for evidence on this assumption). The first two stages can be produced offshore but it is assumed that the third needs to be produced close to the firm headquarters. He shows that multistage production is important to account for the large increase in trade flows relative to GDP in the second half of the 20th century. The reason is that as tariffs and other forms of transport costs of intermediate goods go down, firms choose to do more stages abroad, which increases trade. Tariffs have an amplified effect on trade because they apply to the gross value of the product, not to the value that was added abroad. So a firm that decides to produce the second stage abroad (thus importing it from a subsidiary or an independent supplier) might also need to pay tariffs on the value it added in the first stage, even when the latter was done in the home country. This is a clear example of how an endogenous response of the international organization of production to trade policy can have an important effect on the volume of trade. In a follow up paper, Yi (2008) uses the same idea to estimate trade costs. Multistage production implies that smaller trade costs are needed to explain the lack of international trade relative to national trade (sometime referred to as the 'border effect'). Since measured trade costs are too small to account for the volume of trade, this finding highlights the importance of accounting for this element of the organization of production.

One of the drawbacks of this literature is that the possibilities to fragment production, and

\footnotetext{
${ }^{6}$ See also Deardorff $(2001 \mathrm{a}, \mathrm{b})$.
} 
the characteristics of each fragment (e.g., factor intensities) are exogenous. These exogenous characteristics of the different stages drive most of the results. So the literature has produced a taxonomy of examples in which a whole variety of outcomes are possible depending on the precise way in which fragmentation is introduced. Grossman and Rossi-Hansberg (2008a) avoid this by assuming that production requires a continuum of tasks from each factor of production. So low skilled workers perform a continuum of tasks and high skilled workers perform another continuum of distinct tasks. All tasks are required to produce the good and each task can be done domestically or abroad. Doing the task offshore (in a different location than the firm's headquarters) requires paying a cost that differs by task. Thus, some tasks can be produced offshore easily (like basic manufacturing tasks), while others are very hard or impossible to produce offshore (like local transportation). Which tasks are offshored is part of the production decisions of the firm. The result is a production process that can be embedded in standard trade models to study the impact of the costs of offshoring parts of the production process.

In a Hecksher-Ohlin context, Grossman and Rossi-Hansberg (2008a) show that reductions in the average cost to offshore tasks performed by a given factor have analogous effects to factor-augmenting technological change in that factor. Note the difference with the previous literature. Since in this case tasks are produced with one factor, reductions in the cost of offshoring lead to factor augmenting technological change instead of Hicks neutral technological change in that industry. This implies that reductions in the cost of offshoring low-skilled tasks can lead to gains for all factors of production. Low skilled workers become more 'productive' in the skill abundant country, because they combine their output with the cheaper tasks produced by foreigners. This effect (which they label 'the productivity effect') benefits low skill workers in the skill abundant country. Of course, the standard Stolper-Samuelson effects identified in traditional trade models are still present, so the final impact on low skill workers is uncertain. ${ }^{7}$

All of the studies above focus on the organization of production between countries that have either different technologies or different factor endowments. Tasks are performed offshore because they can be done cheaper or more productively in another country and the costs of producing them abroad are not too large. Baldwin and Robert-Nicoud (2007) discuss the case in which countries have different technologies to produce particular tasks, but similar overall levels of technology. Then, countries can have similar aggregate total factor productivity and still trade 'tasks'. They show that, as in standard Ricardian trade models,

\footnotetext{
${ }^{7}$ Feenstra and Hanson $(1996,1997)$ and Verhoogen (2008) study quality upgrading as a result of the fragmentation of production and analyze empirically the impact on foreign factor prices. Although these are important empirical studies, they do not study the formation and behavior of organizations, but instead focus on product selection.
} 
countries specialize in the production of particular tasks. Otherwise they argue that the basic insights of Grossman and Rossi-Hansberg (2008a) survive this generalization. Grossman and Rossi-Hansberg (2008b) study the pattern of specialization across tasks between countries that are identical except, perhaps, for their size. They introduce external increasing returns at the task level as the source of agglomeration and show that, in general, the larger country in terms of output will have higher wages and specialize in the tasks that are relatively more costly to offshore.

These theories are all static and focus on the organizational problem as related to the international organization of production and trade. None of them studies the dynamics of technology or factor accumulation and how they change as the international organization of production changes. This is an area that clearly requires a lot more work. It is easy to argue that, as the international organization of production involves more locations, technology transfers to these countries change the production possibilities of these countries in the future, or the incentives people have to acquire a better education or particular practical skills. Rodríguez-Clare (2007) is a first effort in this direction. It uses an Eaton and Kortum (2002) setup embedded in a quality-ladder growth model. It then introduces offshoring and analyzes the impact that reductions in offshoring costs may have on growth. He shows that while the rich country always gains from a reduction in offshoring costs in the long run, the poor country may reduce research effort and therefore suffer in the long run. Of course, these insights depend crucially on the particular assumptions used to model the research sector and the potential technological transfers across countries. Hence, although the analysis is intriguing, few final results have been advanced at this stage. ${ }^{8}$

\section{Matching and Factor Heterogeneity}

In the previous section we discussed theories of organization and trade that allow firms to trade the 'tasks' performed in production. The set of required tasks was, however, fixed by assumption. The literature reviewed in this section endogenizes this decision of 'how' to produce, as well as the decision of what exact factors to use in production. In the previous set of papers, the number of factors was small, normally two. Factor heterogeneity was not an element of those theories. As theories go deeper into the decision of how to produce, choosing among heterogenous factors becomes an important part of this decision. A firm can decide

\footnotetext{
${ }^{8}$ Recently, Monge-Naranjo (2008) studied the effect of multinational production on growth via knowledge transfers to local agents that may be internal or external to the firm. His paper is a nice attempt at understanding this important problem, but more empirical and theoretical research is needed to understand how multinational firm and individual worker characteristics shape the transmission of knowledge in source countries, and what are the aggregate implications of this diffusion of knowledge.
} 
to produce using a few very talented individuals and many not so talented assistants or it can hire workers with similar talents. Which option dominates will depend on technology (whether technology is sub or super-modular as explained by Grossman and Maggi, 2000) and on the distribution of talent in the population. Keeping constant the mean of the distribution, a very dispersed distribution of talent (with many very skilled and unskilled individuals), will favor the first type of organization, as agents with intermediate talent will be relatively expensive.

The key requirements on technology for the distribution of skills in the population to matter for the organization of production is for it to exhibit skill complementarity, imperfect substitutability between workers' skill, and differential sensitivity to the skill of different workers (as discussed in Kremer and Maskin, 1996). ${ }^{9}$ A production technology exhibits skill complementarity if better teammates increase the marginal product of a worker. Imperfect substitutability implies that workers with different skills perform different roles in production. In contrast to the theories reviewed in the previous section, it is not the number of units of skill, but how they are distributed across agents within the production team, that determines output. Finally, marginal increases in worker skill have to lead to differential marginal increases in output. Again this is consistent with the notion that different workers perform different roles in production and so the marginal value of their skills, conditional on their teammates, differs. Any technology that satisfies these three basic requirements will lead to a non-trivial organizational problem in which firms will have to decide whom to hire and therefore how to produce.

Perhaps the most basic organizational problem is the one introduced by Lucas (1978). Lucas (1978) assumes that all agents in the economy are heterogenous in their ability to manage, but that all of them are identical as workers. He assumes a production function of the form $A F(n)$ where $A$ is the ability of the one manager employed by the firm (or the entrepreneur) and $n$ is the chosen number of workers. $F(\cdot)$ is assumed to be increasing and concave in the number of workers (other factors could be added as well as long as the function still exhibits diminishing returns to all factors). Note that since everyone is homogenous as a worker, the ability of workers does not enter the production function directly, but the ability of the manager does. Of course, one could think of the ability of workers as determining the level of $F(\cdot)$, which is assumed constant across firms. Lucas (1978) studies the equilibrium occupational decisions that result from an exogenous distribution of managerial skill in the population. Clearly, his technology does not exhibit skill complementarity: the

\footnotetext{
${ }^{9}$ See Legros and Newman (2002) for a nice discussion of the theory of one-to-one matching in equilibrium models and Sattinger (1993) for a review of the use of matching to study labor markets and how to incorporate matching into simple general equilibrium models.
} 
ability of the individual that works as manager does affect the productivity of workers, but the ability as managers of workers does not affect the productivity of the manager. The lack of complementarity implies that there is no well determined matching problem and so the characteristics of the workers that sort into each team is indeterminate (and irrelevant). In this case, the organizational problem reduces to an occupational choice problem. Burstein and Monge-Naranjo (2008) embed this model into a Ricardian international trade model in which home managers can produce abroad. In their case, the productivity of a firm is determined multiplicatively by the ability of the manager, and the characteristics of the country in which they hire workers. Burstein and Monge-Naranjo (2008) uses the model to explore quantitatively the role of this type of cross-country team formation and finds very large negative welfare effects from eliminating this form of offshoring. Particularly interesting is the fact that they can control for local productivity using their theoretical model.

Grossman and Maggi (2000) study a world with two countries and two industries. One of the industries combines the two tasks required for production with a supermodular technology (essentially equivalent to a positive cross-derivative of the production function with respect to the level of the two tasks), and the other with a submodular one (essentially a negative cross-derivative). This means that in the sector with a supermodular technology firms want individuals of the same type. That is, in equilibrium workers match with others like themselves. In contrast, in the submodular industry firms want (given equilibrium factor prices) to combine low and high skilled individuals so there is maximal cross-matching. The result is an allocation in which, in each country, the extreme types (the most and least skilled) are matched with each other, and the intermediate types self-match. Grossman and Maggi (2000) show that if the variance of the skill distribution varies across countries, but the distributions are symmetric with a common mean, the country with higher variance will have comparative advantage in the submodular sector. This paper is a nice example of how the organization of production can affect comparative advantage through the distribution of skills. Note how in this theory the organization of production interacts with a rich set of factor markets to lead to the discussed outcome.

Although undoubtedly very insightful and novel, the analysis has some limitations. Importantly, they assume that matching is one-to-one. Namely, a production process matches only two individuals; one of each type. Hence, the organization of production involves only the talent allocation problem, and no organizational design on top of it. In particular, it is hard to interpret one of the workers as a manager with several subordinates. The analysis is also limited by the fact that the distributions of skill across countries have to be symmetric and differ only in their variance (or diversity as defined in their paper).

Kremer and Maskin (2006) is the first paper to introduce the formation of international 
teams (since in Grossman and Maggi, 2000, all teams are national and economies trade final goods). They present a model in which two agents with different skills can match and produce in a team. Their model uses a Cobb-Douglas production function with coefficients that sum to more than one and are different for the two skills. This technology satisfies the three requirements to have matching. The paper studies the type of international matches that can form in a world with workers of several skills and the wages that workers will command depending on the characteristics of technology and the supply of the different worker's types. The paper provides a useful taxonomy of the possible cases (self-matching, cross-matching, etc.) but does little to discriminate between them. As Grossman and Maggi (2000), it considers only teams with two agents (one-to-one matching). Particularly useful is the discussion of the necessary properties of the technology to have non-trivial matching.

Antràs, Garicano and Rossi-Hansberg (2006) use the hierarchical technology introduced in Garicano (2000) — and developed in general equilibrium with heterogenous agents in Garicano and Rossi-Hansberg (2004, 2006) - to study the impact of the formation of crosscountry teams on the organization of production and wages. A continuum of heterogenous agents in two countries form production teams in which there is one manager and several workers. The production function differs from the Lucas (1978) type technology discussed above in that the span of control (the number of workers per manager) depends on the ability of the workers. ${ }^{10}$ This implies that the technology exhibits complementarity between worker's skills, which in turn leads to positive assortative matching (remember than in Lucas' model there is no matching as worker's skills are irrelevant). More generally, the production function exhibits all the properties discussed in Kremer and Maskin (1996), but it adds team production where one manager is matched to many workers. Hence, in equilibrium there is a skill level below which all agents are workers and above which all agents are managers. Furthermore, complementarity implies positive assortative matching, so the best managers form teams with the best workers. Of course, to the extent that countries have different distributions of skills, if managers can form teams with foreign workers, some will. Whether it is the best or worse managers who form these teams depends on the characteristics of the distribution of skills in both countries. If the north is much more skilled than the south, the worst managers in the north are the ones that form these international teams. Independently of the skill overlap (the range of skills available in both countries when the distributions are assumed uniform), the paper shows that globalization (i.e., the formation of these international teams) implies a reduction in the measure of managers in the relatively skill scarce country. The paper also shows that this reorganization of international production will in-

\footnotetext{
${ }^{10}$ In the theory, workers with more knowledge can solve more problems on their own and therefore use less managerial time as they request help less often.
} 
crease wage inequality in the south, as observed in the data ${ }^{11}$, and will have an ambiguous effect on wage inequality in the north. ${ }^{12}$ Essentially, good workers in the south benefit from the possibility of being matched with better managers in the north. Northern wage inequality can go up if the north is much more skilled and communication technology is particularly good, so the span of control of managers is large.

Antràs, Garicano and Rossi-Hansberg (2006) is the first international trade model to introduce hierarchical one-to-many matching (rather than one-to-one matching), where a manager is endogenously matched with a potentially large number of workers, and the identity of managers and workers is endogenous. Furthermore, the actual team production function results from a micro-founded model of worker specialization in production and knowledge, where the relation between the skill of the manager and that of the worker is mediated by communication technology. An important limitation of the analysis is that most of it is restricted to uniform distributions of skill in both countries. Some of this analysis can be extended easily to more general distributions, but more research on generalizing some these results is needed. ${ }^{13}$

In a follow up paper, Antràs, Garicano and Rossi-Hansberg (2008) takes this framework one step further and analyzes the possibility of multi-layered production teams; namely, teams with more than one layer of managers. In particular it analyzes the case where international teams can have up to three layers. The exercise allows firms to change the number of layers as a response to the economic circumstances and the possibility to organize abroad part of the production process. The paper shows that firms with workers abroad may want to add a layer of managers in the foreign country to deal with simple locally-generated problems; thereby economizing on international communication costs. Whether they decide to introduce this extra layer depends on the difference between local and international communication technologies, and the opportunities of managers in foreign countries to start their own firms.

Understanding the process of introducing and eliminating layers is, we believe, an important topic for future research. Much has been said about the role of information and communication technology in 'flattening the organization,' understood as a reduction in the number of management layers in organizations (see for example Rajan and Wulf, 2006 and Caroli and van Reenen, 2001, among others). The process of introducing new layers to deal

\footnotetext{
${ }^{11}$ See Goldberg and Pavcnik (2007) for a survey of the empirical literature on the effect of globalization on wage inequality in developing countries.

${ }^{12}$ See Feenstra and Hanson (1999) for evidence consistent with this prediction.

${ }^{13}$ Ohnsorge and Trefler (2007), Costinot (2008) and Costinot and Vogel (2008) also introduce worker heterogeneity in standard trade models, but focus on the sorting of workers into industries rather than the matching between different types of workers. Hence, they abstract from the organizational problem.
} 
with the international organization of production has been less studied empirically. As this form of reorganization of production is relatively easy to observe and may have large effects on organizational structure, understanding it seems important to determine the costs and benefits of international production.

Finally, Nocke and Yeaple (2008) present an assignment model of FDI, but focus on the matching between brands of different quality and entrepreneurs of heterogeneous ability. Their analysis is the first to study, in a matching context, the decision of firms to set up or buy the plants they use to produce abroad. As building a new plant abroad is assumed to imply fixed costs, but the value of existing plants is proportional to their productivity and output (and therefore the marginal cost of production), the more productive firms (the ones that ultimately have a larger scale) are the ones that do 'greenfield FDI'; that is, are the ones that build new plants.

\section{Contractual Frictions and Multinational Firm Bound- aries}

The theoretical models that we have reviewed so far enhance our understanding of trade and FDI flows, but they are not able to properly draw the boundaries of multinational firms (MNEs). Some of the models identify a potential gain to fragment production across borders or to use managerial know-how in a foreign country, but they are not designed to explain why these activities will occur within firm boundaries (thus involving foreign insourcing or FDI), rather than through arm's length subcontracting, licensing, or outsourcing. As such, they are not theories of the multinational firm, but theories of the international organization of production.

There is a vast literature in economics that has focused on studying the firm-level decisions of firms related to the mode of servicing a foreign market or the (firm-level) division of stages of production across countries. Markusen (1984) introduced the so-called 'proximityconcentration' trade-off between exporting and multinational activity. Relative to exporting, servicing a foreign market through a local affiliate that replicates the home production process abroad may be appealing because it saves on transportation costs (due to proximity to demand). In the presence of increasing returns to scale, exporting may however prove to be more profitable because it provides the benefits associated with concentrating production in a single location. ${ }^{14}$ A complementary approach was developed by Helpman (1984), who showed that, in the presence of factor price differences across countries and increasing

\footnotetext{
${ }^{14}$ This 'horizontal' approach to MNEs has been extended and empirically tested, among others, by Brainard (1997), Markusen and Venables (1998, 2000), Helpman, Melitz and Yeaple (2004), and Ramondo (2007).
} 
returns to scale in the production of 'headquarter services' (e.g., management know-how, distribution, product-specific R\&D), a producer may find it optimal to fragment the production process and undertake headquarter services and certain manufacturing processes in different countries. Quite naturally, Helpman's (1984) model predicts that measures of the extent of MNE activity should be increasing in relative factor endowment differences across countries. ${ }^{15}$

These technological theories of the multinational firm have provided valuable insights for how MNE activity affects the structure of trade flows, factor price differences, and the diffusion of technology across countries. ${ }^{16}$ Nevertheless, they continue to assume that when fragmentation or replication across borders is profitable, it will be undertaken within firm boundaries. In practice, one of the key organizational decisions of firms is the so-called internalization decision. This is nothing more than the classical 'make-or-buy' decision in industrial organization, but it naturally also applies in an international context. For example, when in 1997, Intel Corporation decided to offshore part of its production of microprocessors to a $\$ 300$ million manufacturing plant in Costa Rica, it also decided to keep full control over that facility, which it wholly owns. Conversely, Nike also relies on offshore manufacturing but instead subcontracts the production of its products to independent producers in Thailand, Indonesia, Cambodia, Vietnam, and other low-wage countries, while keeping within firm boundaries only the design and marketing stages of production.

As we will illustrate below there are many instances in which the internalization decision, just as other organizational decisions, will affect the mapping between factors of production and final goods. At the same time, a growing body of empirical work documents that the internalization decision of multinational firms is very far from random, in the sense that the relative prevalence of foreign insourcing versus foreign outsourcing is systematically related to certain firm, industry and country characteristics. This warrants some explanation. In general, data on the ownership structure of firms is hard to come by. ${ }^{17}$ Fortunately for international trade economists, any exchange of goods or services that crosses a political border is instantly recorded in government statistics. Furthermore, these statistical records often include information on whether the parties transacting the good or service are related

\footnotetext{
${ }^{15}$ Yeaple (2003a) and Hanson, Mataloni and Slaughter (2005) empirically test this 'vertical' view of MNEs. Of course, in the real world, we observe firms undertaking multinational activity due to a combination of horizontal and vertical forces. Yeaple (2003b), Grossman, Helpman, and Szeidl (2006), and Ekholm, Forslid, and Markusen (2007) all study rich theoretical frameworks that unveil interesting complementarities between these two forms of MNE expansion.

${ }^{16}$ See Helpman (1984) and Markusen and Venables (2000) for particularly lucid discussions of the effects on the pattern of trade and factor prices. Ramondo (2007) or Garetto (2008) provide quantitative exercises attempting to measure the welfare consequences of MNE-induced technology diffusion.

${ }^{17}$ This partly explains why the most satisfactory empirical tests of alternative theories of the firm have relied on data on very specific industries.
} 
or not. In the former case, an instance of intrafirm trade occurs, while in the latter case we have interfirm or arm's-length trade. The share of intrafirm trade in world trade is quite large (roughly 1/3): for the case of the United States, it represents close to $50 \%$ of imports and over one-third of exports. Going back to the systematic patterns mentioned above, what the literature has unveiled is that the share of intrafirm trade in total trade varies substantially across industries and countries, and that a significant share of this variation can be explained by certain key characteristics. For instance, Antràs (2003) reports that simple measures of R\&D and capital intensity can explain a large fraction (almost 75\%) of the cross-industry variation in the share of intrafirm imports in total U.S. imports. ${ }^{18}$

These and other stylized facts have motivated a recent wave of theoretical work attempting to shed light on the internalization decision of multinational firms. The main unifying theme of this literature is the departure from the classical assumption of complete contracting. As is well-known (at least since Coase, 1937), firm boundaries are indeterminate in a world in which transactions are governed by comprehensive contracts that specify (in an enforceable way) the course of action to be taken in any possible contingency that the contracting parties may encounter. In order to shed light on the internalization decision, this new literature on multinational firms and outsourcing has thus borrowed from the theoretical literature on firm boundaries and incomplete contracts (c.f., Williamson, 1975, 1985, Grossman and Hart, 1986), and has developed ways to incorporate these contracting frameworks into general equilibrium models. These developments have proved fruitful in explaining the observed systematic patterns in the intrafirm component of trade, and have also been influential in the study of how contractual frictions generally affect the workings of general equilibrium models, as described in the next section. ${ }^{19}$

The first applications of incomplete contracting to open-economy setups adopted the so-called transaction-cost approach of Coase (1937) and Williamson (1975, 1985). This approach describes certain contractual frictions that naturally emerge in arm's-length transactions when contracts are incomplete. Williamson, in particular, formalized how these contractual gaps (and the associated renegotiation or 'fine-tuning' of contracts) would create inefficiencies in situations in which the parties involved in a transaction undertake relationshipspecific investments or use relationship-specific assets. ${ }^{20}$ Essentially, specificity implies that,

\footnotetext{
${ }^{18}$ Similar results are reported in Yeaple (2006), Nunn and Trefler (2008), and Bernard et al. (2008), who all use more detailed datasets than Antràs (2003) and unveil further stylized facts.

${ }^{19}$ In some sense, the stylized facts on intrafirm trade provided prima facie evidence of the importance of incomplete contracting in the real world (how else could one explain those facts?), and this has fostered a burgeoning literature studying organizational choices of firms that transcend the internalization decision (see the next section).

${ }^{20} \mathrm{~A}$ relationship-specific asset or investment is one whose value is higher inside that particular relationship than outside of it.
} 
at the renegotiation stage, parties cannot costlessly switch to alternative trading partners and are partially locked into a bilateral relationship. The combination of bilateral bargaining and sunk costs was shown to potentially generate ex-post inefficiencies (e.g., inefficient termination or execution of the contract) as well as ex-ante or hold-up inefficiencies (e.g., suboptimal provision of relationship-specific investments). An important limitation of the transaction-cost approach is that it has very little to say about the costs of intrafirm transactions. If the market system is so imperfect, why is there not one big firm in the world integrating the production of all goods? The transaction-cost approach simply posits the existence of an exogenous governance cost of running an integrated structure.

An early application of the transaction-cost approach to international economics is offered by Ethier (1986). In Ethier's view, the main difference between transacting within the boundaries of multinational firms and transacting at arm's length is that, in the latter case, headquarters cannot offer quality-contingent contracts to downstream producers or distributors. As a result, headquarters cannot always device a contract that ensures ex-post efficiency and extracts all surplus from their contracting partners. In those situations, the headquarters may be better off integrating the downstream producer. Interestingly, when solving for the general equilibrium of the model, Ethier (1986) finds that integration is more attractive when differences in relative factor endowments between countries are small. This result contrasts with that obtained by Helpman (1984) and nicely illustrates how a microfounded model of the integration decision can radically affect the predictions emanating from models of the international organization of production.

McLaren (2000) and Grossman and Helpman (2002) offer alternative general-equilibrium formalizations of the transaction-cost approach which instead emphasize ex-ante or holdup inefficiencies. In their frameworks, suppliers undertake relationship-specific investments that enhance the value of a good sold by a final-good producer. The key transaction-cost assumption in these models is that the final-good producer can only contractually commit to trade with the supplier at a stipulated price when it vertically integrates it. In the case of outsourcing, the final-good producer will thus have every incentive to hold up the supplier at the ex-post bargaining stage by offering him a relatively low remuneration for the already-sunk investment. Anticipating this ex-post hold up, the supplier will ex-ante choose to provide an inefficient level of investment. Although vertical integration entails an exogenous cost, it may be optimal when the hold-up inefficiencies are large enough. In any case, note that the organizational decision of whether or not to integrate suppliers affects the equilibrium mapping between inputs and final goods.

The most interesting results in McLaren (2000) and Grossman and Helpman (2002) arise when solving for the industry equilibrium of their models, in which a firm's decision 
to vertically integrate its supplier is shown to potentially exert a negative externality on the remaining non-integrated bilateral relationships by thinning the market for inputs. ${ }^{21}$ As a result of these external effects, their models can feature multiple equilibria with a pervasiveness of different organizational forms (or industry systems) in ex-ante identical countries or industries. They can also explain why trade opening, by thickening the market for inputs, may well lead to a worldwide move towards more disintegrated industrial systems, thus increasing world welfare and leading to gains from trade quite different from those emphasized in traditional trade theory. ${ }^{22}$ In other words, the endogenous organizational choices of firms can have a significant effect on the characteristics of an economy's response to a trade liberalization process. ${ }^{23}$

As mentioned above, the transaction-cost approach to the theory of the firm is silent on the sources of costs of vertical integration. In their seminal paper on the property-rights theory of the firm, Grossman and Hart (1986) argue that it is not satisfactory to assume that the contractual frictions that plague the relationship between two nonintegrated firms disappear when these firms integrate. After all, inside firms contracts are incomplete, agents are opportunistic, and it is not clear why integration would change the relationship-specificity of investments. What defines then the boundaries of the firm? The property-rights approach posits that ownership is a source of power when contracts are incomplete. More specifically, when parties encounter contingencies that were not foreseen in the initial contract, the owner of physical assets (e.g., machines, buildings, inventories, patents, copyrights) has these residual rights of control and can decide on the use of these assets that maximizes his payoff at the possible expense of that of the integrated party. Grossman and Hart (1986) then show that in the presence of relationship-specific investments, these considerations lead to a theory of the boundaries of the firm in which both the benefits and the costs of integration are endogenous. In particular, vertical integration entails endogenous costs because it reduces the incentives of the integrated firm to make investments that are partially specific to the integrating firm, thereby lowering the overall surplus of the relationship.

\footnotetext{
${ }^{21}$ The mechanism in the two papers is, however, quite different. In McLaren (2000), a thinner market for inputs reduces the ex-post payoff of suppliers and exacerbates the hold-up problem. The effect in Grossman and Helpman (2002) is instead mediated by a search friction (which again only appears under outsourcing): a thinner market for inputs reduces the probability of finding a match (when the matching function features increasing returns to scale) and this reduces the attractivenes of outsourcing for the remaining non-integrated pairs.

${ }^{22}$ This result is explicitly derived by McLaren (2000). The Grossman and Helpman (2002) setup has been extended in subsequent work by Grossman and Helpman (2003, 2005). Helpman (2006) offers an overview of these papers.

${ }^{23}$ Another organizational decision of firms in the McLaren (2000) and Grossman and Helpman (2002) papers is the choice by suppliers of the degree to which they customize their intermediate products to their intended buyers. See also Qiu and Spencer (2002) and Chen and Feenstra (2008) for related work.
} 
The property-rights approach has been applied to international trade environments, among others, by Antràs (2003) and Antràs and Helpman (2004, 2008). These papers envision an incomplete-contracting world in which both final-good producers and suppliers (who may be located in a different country) undertake non-contractible, relationship-specific investments that enhance value. The situation is thus one of double-sided hold-up and leads to suboptimal investments by both types of producers. As in Grossman and Hart (1986), vertical integration does not affect the space of contracts: it simply entails a stronger bargaining power for the final-good producer in its negotiations with the supplying division. The key partial equilibrium result in these papers is that vertical integration is only optimal when the elasticity of output (or sales) with respect to the final-good producer's noncontractible investments is large relative to the elasticity of output (or sales) with respect to the supplier's noncontractible investments. In other words, integration dominates outsourcing in 'headquarter-intensive' industries, but the converse is true in industries with low-headquarter intensity (or 'component-intensive' industries, to use the terminology in Antràs and Helpman, 2004).

Antràs (2003) embeds this structure in a general equilibrium model of international trade featuring increasing returns, product differentiation and monopolistic competition (c.f., Helpman and Krugman, 1985). He argues that, in practice, non-contractible investments carried out by final-good producers are likely to be more capital-intensive than those undertaken by supplying firms (see his paper for evidence). As a result, the model delivers a positive association between capital intensity and the attractiveness of integration. In the open-economy model, this in turn produces a positive correlation, at the industry level, between capital intensity and the share of intrafirm trade in world trade, which is one of the stylized facts mentioned above. ${ }^{24}$ Furthermore, when solving for the general equilibrium of the model, the model also predicts a positive correlation between a country's relative capital abundance and the share of intrafirm exports in its total exports to any country, a prediction for which Antràs (2003) again finds strong support.

Antràs and Helpman (2004) develop a property-rights theory of the multinational firm that allows for intraindustry heterogeneity in productivity and for differential fixed costs across different organizational models, as in Melitz (2003) or Helpman, Melitz, and Yeaple (2004). As a result, their model delivers equilibria featuring multiple organizational forms within an industry. Independently of the assumptions on fixed costs, the framework continues to predict a relative prevalence of foreign insourcing (or FDI) over outsourcing in relatively

\footnotetext{
${ }^{24}$ The fact that the share of intrafirm imports in total U.S. imports is also significantly positively correlated with $R \& D$ intensity can also be explained by the property-rights approach, as R\&D intensity is another natural proxy for 'headquarter intensity'.
} 
headquarter intensive industries. Furthermore, under the natural assumption that fixed costs are larger when sourcing in foreign countries than when doing so within firm boundaries, the model predicts that only the most productive firms in an industry should be expected to vertically integrate their foreign suppliers. Antràs and Helpman (2004) study the relative prevalence of different organizational forms and derive predictions that go well beyond those derived in Antràs (2003) and that open the door for more complete empirical studies of the characteristics of the international organization of production. Antràs and Helpman (2008) further extend the framework to allow for partial contractibility of investments and show that, contrary to what would have been predicted by a transaction-cost theory of the multinational firm, improvements in contractibility in a country can actually lead to increase in the prevalence of FDI (over outsourcing) in this country.

We have so far focused on an overview of the key theoretical contributions to the literature on contractual frictions and multinational firm boundaries. Recent efforts have been directed towards the development of empirical tests of the property-rights model of the multinational firm, as exemplified by Feenstra and Hanson (2005), Yeaple (2006), Defever and Toubal (2007), Tomiura (2007), Bernard et al. (2008) and Nunn and Trefler (2008). All these papers focus, however, on testing particular predictions of particular variants of the property-rights model, rather than offering a structural test of the model. Furthermore, as of current time, there has been no satisfactory attempt to properly deal with a set of econometric biases (identified by the same model) that will arise when attempting to test the model. ${ }^{25}$ In our view, future research efforts should be aimed in that direction.

Another potentially fruitful area for future research relates to the study of the effects of the non-appropriable nature of knowledge on the internalization decision. Past research has arguably focused too much on hold-up inefficiencies as the main drivers of the internalization decision. Our example of the choice of Intel to fully internalize their operations in Costa Rica is probably better explained in terms of a fear of technological expropriation than in terms of a double-sided hold-up problem. An early attempt to incorporate a notion of non-appropriable knowledge into a general equilibrium model of the multinational firm was developed by Ethier and Markusen (1996), who adopted a transaction-cost approach in which FDI avoided any type of knowledge dissipation. A more satisfactory approach would entail the application of the property-rights approach and of the notion of 'access' developed by Rajan and Zingales (2001).

\footnotetext{
${ }^{25}$ For example, the property-rights model predicts that capital intensity and R\&D intensity will be higher in integrated firms relative to non-integrated firms. The observed positive correlation between the share of intrafirm trade and capital and R\&D intensity at the industry level could thus be partly explained by these forces, rather than by the selection of firms into integration or outsourcing.
} 


\section{Contractual Frictions and Other Organizational De- cisions}

The papers surveyed in the previous section focus on the internalization decision as the main organizational choice of firms. The systematic patterns observed in the outsourcing decisions of firms suggest that we live in a world of incomplete contracting. A natural question to ask is then: how do contractual frictions affect the other organizational choices of firms? And how do these choices interact with international trade? The available literature has only provided tentative answers to these questions.

Soon after the development of the 'complete' theories of multinational firm boundaries described above, the literature acknowledged that imperfect contracting could affect not only the ownership structure of firms but also their geographical location, hence creating a link with the literature on fragmentation reviewed in section 2. Antràs (2005) argues that the incomplete nature of contracts governing international transactions limits the extent to which the production process can be fragmented across borders. In a dynamic, general-equilibrium Ricardian model of North-South trade, he shows that the incompleteness of international contracts naturally leads to the emergence of Vernon-type product cycles, with new goods being initially manufactured in North (where product development takes place), and only later (when the goods are mature) is manufacturing carried out in South. ${ }^{26}$

Acemoglu et al. (2007), Costinot (2007), Levchenko (2007), and Nunn (2007) argue that contractual frictions can shape the location of production and thus the structure of trade flows even in models without any fragmentation of production. In particular, to the extent that contractual frictions lead to organizational choices by firms that affect the mapping between inputs and outputs differentially across sectors, imperfect contracting will be a source of comparative advantage: countries with well-functioning contractual institutions will be net exporters of 'contract-intensive' goods. These papers differ in their proposed measure of contract-dependence and in other particulars aspects. Acemoglu et al. (2007) build a micro-founded model of technology adoption (another organizational decision of firms) in the presence of incomplete contracting, and show that greater contractual incompleteness leads to the adoption of less advanced technologies, with the effect being more pronounced when there is greater complementary among intermediate inputs. Costinot (2007) develops a model where productivity is determined by the division of labor, and the extent of the latter is affected by the contractual environment and by the complexity of production; he

\footnotetext{
${ }^{26}$ Antràs (2005) also draws the boundaries of multinational firms and shows that the model gives rise to a new version of the product cycle in which manufacturing is shifted to the South first within firm boundaries, and only at a later stage to independent firms in the South. See Puga and Trefler (2007) for another theoretical exploration of the links between contractual incompleteness and product cycles
} 
then derives the result that countries with better contracting institutions have comparative advantage in more complex sectors (for which he finds support in the data). Levchenko (2007) and Nunn (2007) also provide empirical evidence that a country's comparative advantage is partly determined by contracting institutions, and suggest measures of contract dependence related to the costs of contracting between upstream and downstream producers. ${ }^{27}$

Another important organizational decision of firms concerns the allocation of decision rights among employees. In the presence of noncontractible effort decisions by workers, managers face a trade-off between granting decision rights to workers or keeping these to themselves. The former option has the benefit of providing workers with 'initiative,' which may lead to higher effort, but delegation may result in decisions that are not necessarily optimal from the point of view of the manager. Avoiding delegation (i.e., exerting 'authority') tends to inhibit the initiative of workers but entails more control over the course of production. As a result of these forces, the reduced-form mapping between factors of production and goods is affected by the allocation of decision rights among agents. This trade-off was first formalized by Aghion and Tirole (1997) and has been applied to general-equilibrium frameworks by Puga and Trefler (2002) and Marin and Verdier (2008a,b).

In certain situations, managers may have access to simpler ways to provide incentives to workers. For instance, the remuneration of a worker can be made conditional on an observable (and verifiable) variable that is in turn affected by the worker's effort decision. Holmstrom (1982) and Holmstrom and Milgrom (1994) have emphasized the role of contingent rewards in influencing workers' incentives. A much less understood question is how trade liberalization affects the 'slope' of this incentive scheme and how this endogenous change affects the response of the economy to trade opening. Grossman and Helpman (2004) and Vogel (2007) provide preliminary answers to these questions but much more work is required in this area.

A final potentially fruitful avenue of research concerns the role of trade policy in a world where firms make organizational decisions under incomplete contracts. A first attempt in this direction is provided by Antràs and Staiger (2008), who study the implications of the fact that in transactions involving significant ex-ante customization of goods, any renegotiation of the contract will lead to a price that is determined by bilateral bargaining and not by market clearing conditions, as in traditional theory. As a result, they show that trade policy changes in local prices can have spillover effects in other countries, even when they hold constant international (untaxed) prices, thus leading to predictions quite distinct from those of the traditional terms-of-trade theory of trade agreements. Conconi, Legros and Newman (2009)

\footnotetext{
${ }^{27}$ Levchenko (2007) also develops an interesting theoretical model that illustrates how contractual incompleteness can significantly impact the workings of a general equilibrium model. For instance, in his model, the institutionally-weak country may not gain from trade, and factor prices may actually diverge as a result of trade.
} 
have studied additional implications of incomplete contracting for the design of optimal trade policy.

\section{Concluding Remarks}

In reviewing the literature on organizations and trade we have, inevitably, disregarded many related papers and topics in order to give the reader a summary of what we believe are the main recent advances in our understanding of the role of organizations in trade. We have divided the literature into four sections, but we could have added several more. In particular, we could have included a discussion of the literature on heterogenous firms that emanated from the seminal work of Melitz (2003). ${ }^{28}$ We could have also reviewed the recent literature on multiproduct firms (e.g. Bernard, Redding and Shott, 2006). ${ }^{29}$ As explained in the introduction, our guiding principle was that these topics, although important, do not deal with the way production is organized, but rather focus on what is produced and who produces it. These are obviously important questions, but we had to draw the line somewhere and we are undoubtedly biased towards our own idiosyncratic interests.

The discussion of the different strands of the literature has allowed us to outline some possible ideas for future research and what we view as 'gaps' in the current understanding of this topic. More generally, there are four large areas in which we would particularly welcome more research.

First, most of the literature on organizations and trade is static. There are only a few papers that study the dynamic impact of the international organization of production on the evolution of knowledge, the distribution of skills, and other country-specific characteristics. Could the fragmentation of production lead to skill upgrading in developing countries? How will the pattern of specialization evolve given this type of learning? Will global production chains imply convergence in income levels? All these are questions that have been mostly relegated to a few lines in the discussion of static frameworks. Theoretical work in this area is badly needed.

Second, although the literature has incorporated many organizational theories into trade frameworks, there are many alternative theories of organizations that are still awaiting a general equilibrium implementation. These alternative approaches could also yield important insights into the way the international organization of production affects aggregate outcomes. Perhaps even more important is to make an effort to synthesize what are the robust economic predictions and effects of all these different organizational theories that we need to incor-

\footnotetext{
${ }^{28}$ See the survey in Helpman (2006) who does cover this literature.

${ }^{29}$ See the survey in Bernard, et. al. (2007).
} 
porate into trade frameworks. We may believe that the efficient use of information drives organizational structure or that 'authority' and 'delegation' are the key elements, but can we obtain common robust aggregate predictions from these theories for trade?

We have made an effort to discuss the instances in which the theories we outlined in this survey are consistent with particular empirical facts or are motivated by them. However, even though some suggestive evidence is available to contrast these theories, most of empirical work takes a reduced-form approach in which only the predictions of the theory on the sign of some correlations are contrasted with the data. Very little work has been devoted to structurally estimate the models we have discussed in this survey. This is partly due to the stylized nature of some of these theories, and partly due to the under-utilization of this type of empirical techniques in the international trade field. The literature on heterogenous firms has taken more advantage of this type of methodology with extremely interesting, and much more robust, results. We hope to see the evolution of similar empirical work on the questions we have discussed in this survey.

Finally, although the literature on organizations and trade has been extremely concerned with matching positive features of reality (e.g., the share of intrafirm trade, the volume of trade, the evolution of wage inequality), it has been much less concerned with the normative and policy implications of changes in the international organization of production. A lot more work is needed to quantitatively assess the magnitude of the observed changes, their welfare impact and, if necessary, the possible policy responses. 


\section{Literature Cited}

Acemoglu, Daron, Pol Antràs, and Elhanan Helpman (2007), "Contracts and Technology Adoption," American Economic Review, Vol. 97, No. 3, pp. 916-943.

Aghion, Philippe and Jean Tirole (1997), "Formal and Real Authority in Organizations," Journal of Political Economy, Vol. 105, No. 1, pp. 1-29.

Antràs, Pol (2003), "Firms, Contracts, and Trade Structure," Quarterly Journal of Economics, 118:4, pp. 1375-1418.

Antràs, Pol (2005), "Incomplete Contracts and the Product Cycle," American Economic Review, 95:4, pp. 1054-1073.

Antràs, Pol, Luis Garicano and Esteban Rossi-Hansberg (2006), "Offshoring in a Knowledge Economy," Quarterly Journal of Economics, , Vol. 121, No. 1, pp. 31-77.

Antràs, Pol, Luis Garicano and Esteban Rossi-Hansberg (2008), "Organizing Offshoring: Middle Managers and Communication Costs," forthcoming in E. Helpman, D. Marin, and T. Verdier (eds.), The Organization of Firms in a Global Economy, Harvard University Press.

Antràs, Pol and Elhanan Helpman (2004), "Global Sourcing," Journal of Political Economy, 112, pp.552-580.

Antràs, Pol and Elhanan Helpman (2008), "Contractual Frictions and Global Sourcing," forthcoming in E. Helpman, D. Marin, and T. Verdier (eds.), The Organization of Firms in a Global Economy, Harvard University Press.

Antràs, Pol and Robert W. Staiger (2008), "Offshoring and the Role of Trade Agreements," mimeo Harvard University.

Arndt, Sven W. (1997), "Globalization and the Open Economy," North American Journal of Economics and Finance, 8:1, 71-79.

Baldwin, Richard, (2006), "Globalisation: The great unbundling(s)," Economic Council of Finland.

Baldwin, Richard and Frederic Robert-Nicoud, (2007), "Offshoring: General Equilibrium Effects on Wages, Production and Trade," NBER Working Paper No. 12991.

Bernard, Andrew B., Stephen J. Redding and Peter K. Schott, (2006), "Multi-Product Firms and Product Switching," NBER Working Paper 12293.

Bernard, Andrew B., J. Bradford Jensen, Stephen Redding, and Peter K. Schott (2008), "IntraFirm Trade and Product Contractibility," mimeo Dartmouth College.

Bernard, Andrew B., Stephen J. Redding and Peter K. Schott, (2007), "Firms in International Trade," Journal of Economic Perspectives, 21:3, 105-130. 
Brainard, S. Lael (1997), "An Empirical Assessment of the Proximity-Concentration Trade-off Between Multinational Sales and Trade," American Economic Review, 87:4, pp. 520-544.

Burstein, Ariel and Alexander Monge-Naranjo, (2008), "Foreign Know-How, Firm Control, and the Income of Developing Countries," forthcoming in the Quarterly Journal of Economics.

Caroli, Eve and John Van Reenen, (2001), "Skill-Biased Organizational Change? Evidence From A Panel Of British And French Establishments," Quarterly Journal of Economics, 116:4, 1449-1492.

Chen, Yongmin and Robert C. Feenstra (2008), "Buyer Investment, Export Variety and Intrafirm Trade," European Economic Review, forthcoming.

Coase, Ronald H. (1937), "The Nature of the Firm," Economica, 4:16, pp. 386-405.

Conconi Paola, Patrick Legros, Andrew Newman (2009), "Trade Liberalization and Organizational Change," Working Paper Boston University.

Costinot, Arnaud (2007), "On the Origins of Comparative Advantage," mimeo University of California at San Diego.

Costinot, Arnaud (2008), "Heterogeneity and Trade," mimeo University of California at San Diego.

Costinot, Arnaud and Jonathan Vogel (2008), "Matching and Inequality in the World Economy," mimeo University of California at Los Angeles.

Deardorff, Alan V., (2001a), "Fragmentation across Cones," in S.W. Arndt and H. Kierzkowski, eds., Fragmentation: New Production Patterns in the World Economy, Oxford: Oxford University Press.

Deardorff, Alan V., (2001b), "Fragmentation in Simple Trade Models," North American Journal of Economics and Finance, 12:2, 121-137.

Defever, Fabrice and Farid Toubal (2007), "Productivity and the Sourcing Modes of Multinational Firms: Evidence from French Firm-Level Data," mimeo University of Paris.

Dixit, Avinash K and Grossman, Gene, (1982), "Trade and Protection with Multistage Production," Review of Economic Studies, 49(4), 583-594.

Eaton, Jonathan and Samuel Kortum, (2002), "Technology, Geography, and Trade," Econometrica, 70:5, 1741-1779.

Egger, Hartmut and Falkinger, Josef, (2003), "The Distributional Effects of International Outsourcing in a 2x2 Model," North American Journal of Economics and Finance, 14:2, 189-206.

Ekholm, Karolina, Rikard Forslid and James R. Markusen (2007), "Export-Platform Foreign Direct Investment," Journal of the European Economic Association, Vol. 5, No. 4, Pages 776-795. 
Ethier, Wilfred J. (1986), "The Multinational Firm," Quarterly Journal of Economics, 101:4, pp. 805-833.

Ethier, Wilfred J. and James R. Markusen (1996), "Multinational Firms, Technology Diffusion and Trade," Journal of International Economics, 41:1, pp. 1-28.

Feenstra, Robert C. and Gordon H. Hanson, (1996), "Foreign Investment, Outsourcing and Relative Wages," in R.C. Feenstra, G.M. Grossman and D.A. Irwin, eds., The Political Economy of Trade Policy: Papers in Honor of Jagdish Bhagwati, Cambridge, MA: The MIT Press.

Feenstra, Robert C. and Gordon H. Hanson (1997), "Foreign Direct Investment and Relative Wages: Evidence from Mexico's Maquiladoras," Journal of International Economics, vol. 42(3-4), pp. 371-393.

Feenstra, Robert C. and Gordon H. Hanson, (1999). "The Impact Of Outsourcing And HighTechnology Capital On Wages: Estimates For The United States, 1979-1990," The Quarterly Journal of Economics, 114:3, 907-940.

Feenstra, Robert C., and Hanson, Gordon H. (2005), "Ownership and Control in Outsourcing to China: Estimating the Property Rights Theory of the Firm," Quarterly Journal of Economics, 120(2): 729-762.

Findlay, Ronald and Harry Grubert (1959), "Factor Intensity, Technological Progress, and the Terms of Trade," Oxford Economic Papers, Vol. 11:1, p. 111-121.

Garetto, Stefania (2008), "Input Sourcing and Multinational Production," mimeo University of Chicago.

Garicano, Luis (2000), "Hierarchies and the Organization of Knowledge in Production," Journal of Political Economy, 108:5, 874-904.

Garicano, Luis and Esteban Rossi-Hansberg (2004), "Inequality and the Organization of Knowledge," American Economic Review P\&SP, 94:2, 197-202.

Garicano, Luis and Esteban Rossi-Hansberg (2006), "Organization and Inequality in a Knowledge Economy," Quarterly Journal of Economics, 121:4, 1383-1435.

Goldberg, Pinelopi K. and Nina Pavcnik (2007), "Distributional Effects of Globalization in Developing Countries," Journal of Economic Literature, 45:1, 39-82.

Grossman, Sanford J., and Oliver D. Hart (1986), "The Costs and Benefits of Ownership: A Theory of Vertical and Lateral Integration," Journal of Political Economy, 94:4, pp. 691719 .

Grossman, Gene M. and Elhanan Helpman (2002), "Integration vs. Outsourcing in Industry Equilibrium," Quarterly Journal of Economics 117 (1), 85-120. 
Grossman, Gene M., and Elhanan Helpman (2003), "Outsourcing versus FDI in Industry Equilibrium," Journal of the European Economic Association, 1(2-3): 317-27.

Grossman, Gene M., and Elhanan Helpman (2004), "Managerial Incentives and the International Organization of Production," Journal of International Economics, 63(2): 237-62.

Grossman, Gene M., and Elhanan Helpman (2005), "Outsourcing in a Global Economy," Review of Economic Studies, 72(1): 135-59.

Grossman, Gene, Elhanan Helpman and Adam Szeidl (2006), "Optimal Integration Strategies for the Multinational Firm," Journal of International Economics, vol. 70, September, pp. 216-238.

Grossman, Gene M. and Giovanni Maggi, (2000), "Diversity and Trade," American Economic Review, 90:5, 1255-1275.

Grossman, Gene M. and Esteban Rossi-Hansberg, (2008a), "Trading Tasks: A Simple Theory of Offshoring," forthcoming in the American Economic Review.

Grossman, Gene M. and Esteban Rossi-Hansberg, (2008b), "Task Trade between Similar Countries," mimeo Princeton University.

Hanson, Gordon H., Raymond J. Mataloni and Matthew J. Slaughter, (2005), "Vertical Production Networks in Multinational Firms," Review of Economics and Statistics, 87:4, 664-678.

Helpman, Elhanan (1984), "A Simple Theory of International Trade with Multinational Corporations", Journal of Political Economy, 92:3, pp. 451-471.

Helpman, Elhanan (2006), "Trade, FDI and the Organization of Firms," Journal of Economic Literature, 44, pp.589-630.

Helpman, Elhanan and Paul R. Krugman (1985), Market Structure and Foreign Trade, Cambridge, MA: MIT Press. Chapter 12.

Helpman, Elhanan, Marc J. Melitz, and Stephen R. Yeaple (2004), "Export versus FDI with Heterogeneous Firms," American Economic Review 94:1, pp.300-316.

Holmstrom, Bengt (1982), "Moral Hazard in Teams," Bell Journal of Economics, Vol. 13, No. 2, pp. 324-340.

Holmstrom, Bengt and Paul Milgrom (1994), "The Firm as an Incentive System," American Economic Review, 84:4, pp. 972-991.

Hummels, David, Jun Ishii and Kei-Mu Yi, (2001), "The Nature and Growth of Vertical Specialization in World Trade," Journal of International Economics, 54:1, 75-96.

Hummels, David, Dana Rapoport, and Kei-Mu Yi, (1998), "Vertical Specialization and the Changing Nature of World Trade," Federal Reserve Bank of New York Economic Policy Review, $4: 2,79-99$. 
Jones, Ronald W. (1965), "The Structure of Simple General Equilibrium Models," Journal of Political Economy, 73, pp. 557-572.

Jones, Ronald W. and Henryk Kierkowski, (1990), "The Role of Services in Production and International Trade: A Theoretical Framework," in R. Jones and A. Kruegers, eds., The Political Economy of International Trade: Essays in Honor of Robert E. Baldwin, Oxford: Basil Blackwell.

Jones, Ronald W. and Henryk Kierzkowski, (2001), "Globalization and the Consequences of International Fragmentation," in R. Dornbusch, ed., Money, Capital Mobility and Trade: Essays in Honor of Robert A. Mundell, Cambridge, MA: The MIT Press.

Kohler, Wilhelm, (2004a), "Aspects of International Fragmentation," Review of International Economics, 12:5, 793-816.

Kohler, Wilhelm, (2004b), "International Outsourcing and Factor Prices with Multistage Production," Economic Journal, 114:1, 166-168.

Kremer, Michael and Eric Maskin, (1996), "Wage Inequality and Segregation by Skill," NBER Working Paper 5718.

Kremer, Michael and Eric Maskin, (2006), "Globalization and Inequality," mimeo Harvard University.

Legros, Patrick and Andrew F. Newman, (2002), "Monotone Matching in Perfect and Imperfect Worlds," Review of Economic Studies, 69:4, 925-942.

Levchenko, Andrei (2007), "Institutional Quality and International Trade," Review of Economic Studies, 74:3, 791-819.

Lucas, Robert E. Jr., (1978), "On the Size Distribution of Business Firms," Bell Journal of Economics, 9:2, 508-523.

Marin, Dalia and Thierry Verdier (2008a), "Power Inside The Firm and The Market: A General Equilibrium Approach," Journal of the European Economic Association, vol. 6(4), pp. 752788.

Marin, Dalia and Thierry Verdier (2008b), "Corporate Hierarchies and the Size of Nations: Theory and Evidence," mimeo University of Munich.

Markusen, James R. (1984), "Multinationals, Multi-Plant Economies, and the Gains from Trade," Journal of International Economics, 16, pp. 205-226.

Markusen J. and A. Venables (1998): "Multinational Firms and the New Trade Theory", Journal of International Economics, 46(2), 183-203.

Markusen, James R. and Anthony J. Venables (2000), "The Theory of Endowment, Intra-industry and Multi-national Trade," Journal of International Economics, 52, pp. 209-234. 
McLaren, John (2000), "Globalization and Vertical Structure," American Economic Review 90:5, pp.1239-1254.

Melitz, Marc J. (2003), "The Impact of Trade on Intra-Industry Reallocations and Aggregate Industry Productivity," Econometrica, 71:6, pp. 1695-1725.

Monge-Naranjo, Alexander, (2008), "Foreign Firms, Domestic Entrepreneurial Skills and Development," mimeo Northwestern University.

Nocke, Volker and Stephen Yeaple, (2008), "An Assignment Theory of Foreign Direct Investment," Review of Economic Studies, 75:2, 529-557.

Nunn, Nathan (2007) "Relationship Specificity, Incomplete Contracts and the Pattern of Trade," Quarterly Journal of Economics, Vol. 122, No. 2, pp. 569-600.

Nunn, Nathan and Daniel Trefler (2008), "The Boundaries of the Multinational Firm: An Empirical Analysis," forthcoming in E. Helpman, D. Marin, and T. Verdier (eds.), The Organization of Firms in a Global Economy, Harvard University Press.

Ohnsorge, Franziska and Daniel Trefler (2007), "Sorting it Out: International Trade and Protection with Heterogeneous Workers," Journal of Political Economy, 115 pp. 868-892.

Puga, Diego and Daniel Trefler (2002), "Knowledge Creation and Control in Organizations," NBER Working Paper No. 9121.

Puga, Diego and Daniel Trefler (2007), "Wake Up and Smell the Ginseng: The Rise of Incremental Innovation in Low-Wage Countries," mimeo University of Toronto.

Qiu, Larry D. and Barbara Spencer (2002), "Keiretsu and Relationship-Specific Investment: Implications for Market-Opening Trade Policy," Journal of International Economics, vol. 58(1), pp. $49-79$.

Rajan, Raghuram G and Julie Wulf, (2006), "The Flattening Firm: Evidence from Panel Data on the Changing Nature of Corporate Hierarchies," Review of Economics and Statistics, 88:4, 759-773.

Rajan, Raghuram G. and Luigi Zingales (2001), "The Firm as a Dedicated Hierarchy: A Theory of the Origins and Growth of Firms," Quarterly Journal of Economics, 116, pp. 805-852.

Ramondo, Natalia (2007), "Size, Geography, and Multinational Production," mimeo University of Texas at Austin.

Rodríguez-Clare, Andrés, (2007), "Offshoring in a Ricardian World," NBER Working Paper No. 13203.

Sattinger, Michael, (1993), "Assignment Models of the Distribution of Earnings," Journal of Economic Literature, 31:2, 831-880. 
Spencer, Barbara (2005), "International Outsourcing and Incomplete Contracts," Canadian Journal of Economics, Vol. 38, No. 4, pp. 1107-1135

Tomiura, Eiichi (2007), "Foreign Outsourcing, Exporting, and FDI: A Productivity Comparison at the Firm Level," Journal of International Economics, Vol. 72, pp. 113-127.

Verhoogen, Eric, (2008), "Trade, Quality Upgrading and Wage Inequality in the Mexican Manufacturing Sector," Quarterly Journal of Economics, 123:2, 489-530.

Vogel, Jonathan (2007), "Institutions and Moral Hazard in Open Economies," Journal of International Economics, Volume 71:2, pp. 495-514.

Williamson, Oliver E. (1975), Markets, Hierarchies: Analysis, Antitrust Implications, Free Press: New York.

Williamson, Oliver E. (1985), The Economic Institutions of Capitalism, Free Press. Chapters 1-3.

Yeaple, Stephen (2003a), "The Role of Skill Endowments in the Structure of U.S. Outward FDI," Review of Economics and Statistics, August, 85(3), pp. 726-734.

Yeaple, Stephen (2003b), "The Complex Integration Strategies of Multinationals and Cross Country Dependencies in the Structure of FDI," Journal of International Economics, 60, pp. 293-314.

Yeaple, Stephen R. (2006), "Foreign Direct Investment, and the Structure of U.S. Trade," Journal of the European Economic Association, 4, pp.602-611.

Yi, Kei-Mu, (2003), "Can Vertical Specialization Explain the Growth of World Trade?," Journal of Political Economy, 111:1, 52-102.

Yi, Kei-Mu, (2008), "Vertical Specialization and the Border Effect," mimeo Federal Reserve Bank of Philadelphia. 